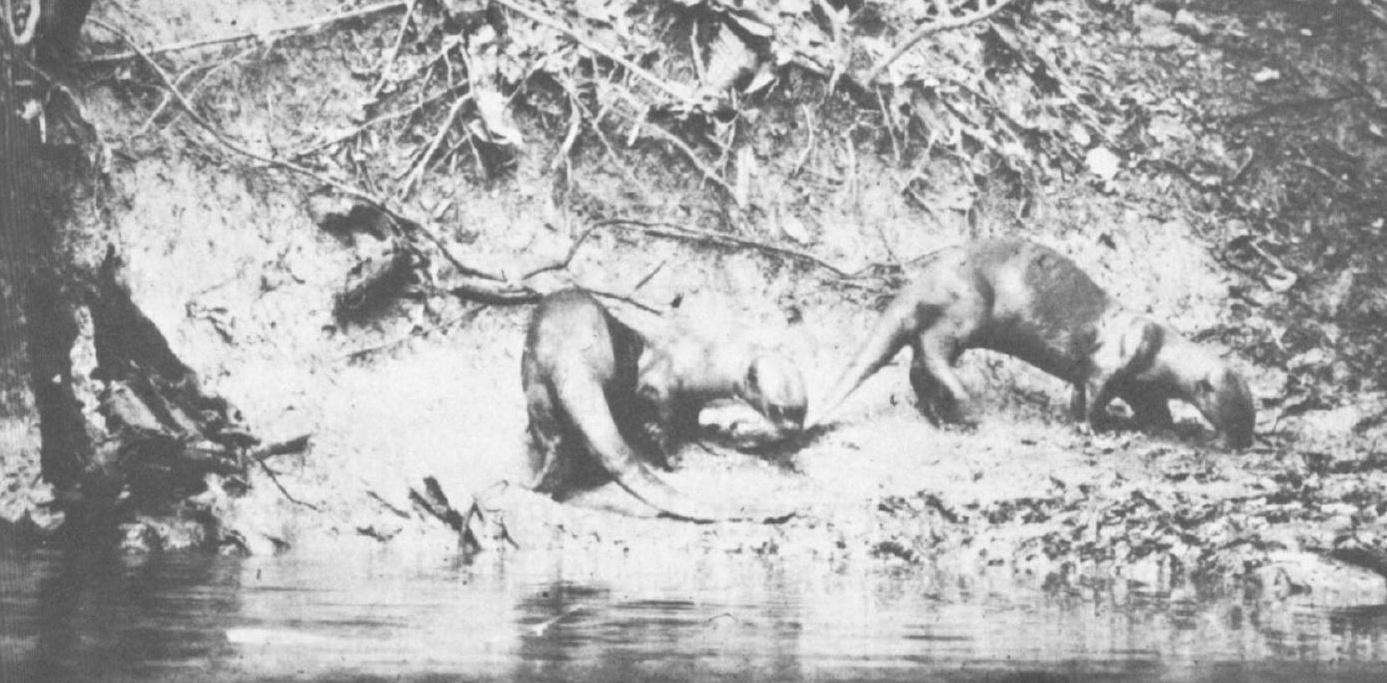

\section{GIANT OTTERS IN SURINAM}

After almost two years spent on field surveys of the giant otter Pteronura brasiliensis in Surinam, Nicole Duplaix concludes that this is one of the few countries where numbers are stable and the outlook for the species bright, at least in the interior. Surinam's conservation laws are effective, reserves are protected, and apparently otters are not commonly killed for their pelts except perhaps on the French Guiana border. Dr Duplaix investigated 13 major rivers, 62 creeks and one lake, and made a special study of the Kaboeri creek, a tributary of the Corantijn river on the western frontier with Guyana, where she found the highest density of otters. Unfortunately, the local Indian people are opposed to the two proposed reserves, on the river and the creek respectively, as intrusions on their ancestral hunting and fishing grounds. Her work was supported by the New York Zoological Society, the National Geographic Society, WWF(USA) and the Rare Animal Relief Effort. Dr Duplaix's photographs include one (bottom right) of an otter 'camp', where otters have cleared the vegetation and which they use for grooming and resting.
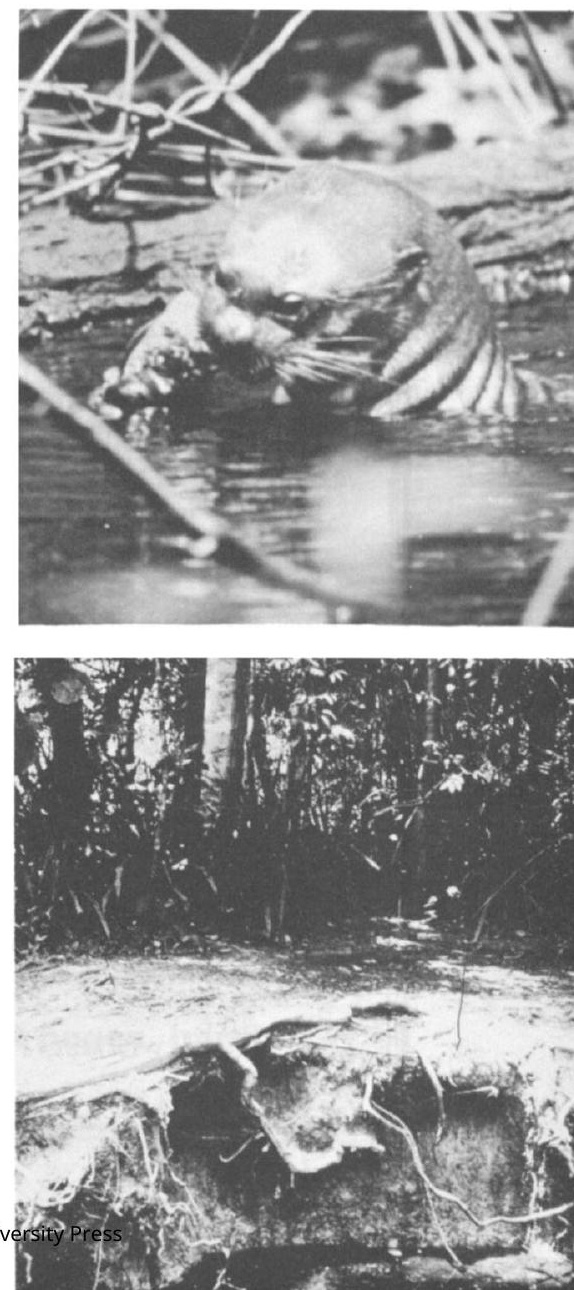
In support of the Fauna Preservation Society's Otter Haven Project

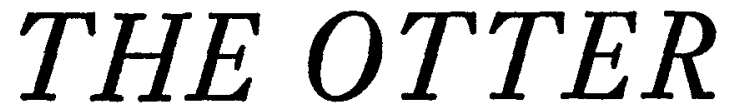

A BRONZE

sculpted by

\section{MICHAEL RIZZELLO}

President of the Royal Society of British Sculptors

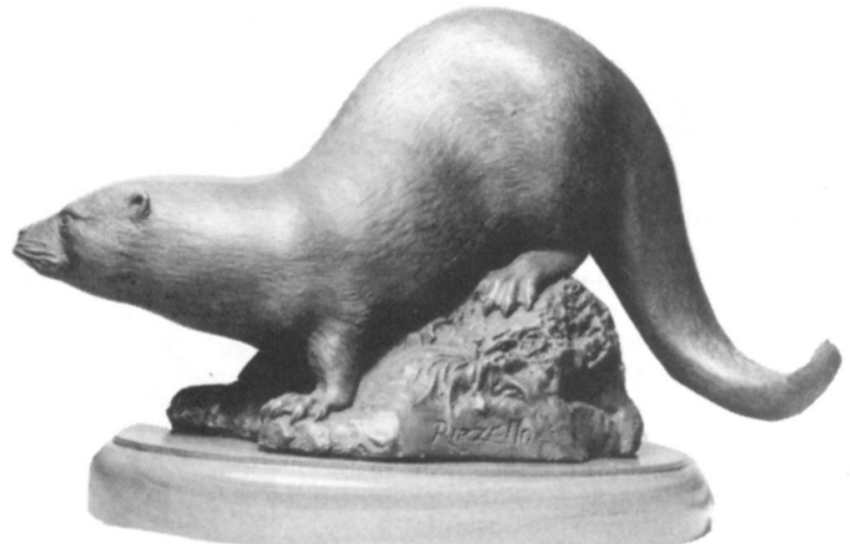

In the tradition of the 19th century French Animaliers, Michael Rizzello has created this acutely observed study of the otter, working from life. The otter is caught for an instant in that instinctively wary pose on the edge of the river bank before it slides into the water.

Cast by the ages-old 'lost wax' method, the Otter is available in an edition limited absolutely to 200 copies world-wide, each mounted on a plinth of English oak from Windsor Great Park.

The price of $£ 432$ or $\$ 900$ includes two facsimile reproductions of the working drawings, VAT (or import duty) and security delivery. For an illustrated brochure please write to:

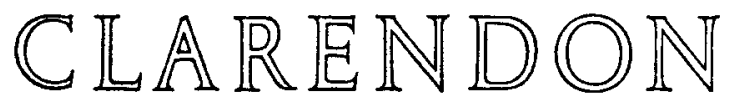

FINE ART LIMITED

2 Friday Street, Henley-on-Thames, Oxfordshire RG9 $1 A H$ Telephone: 049124103 


\section{THE PENITENT BUTCHERS}

\section{by Richard Fitter illustrated by Sir Peter Scott}

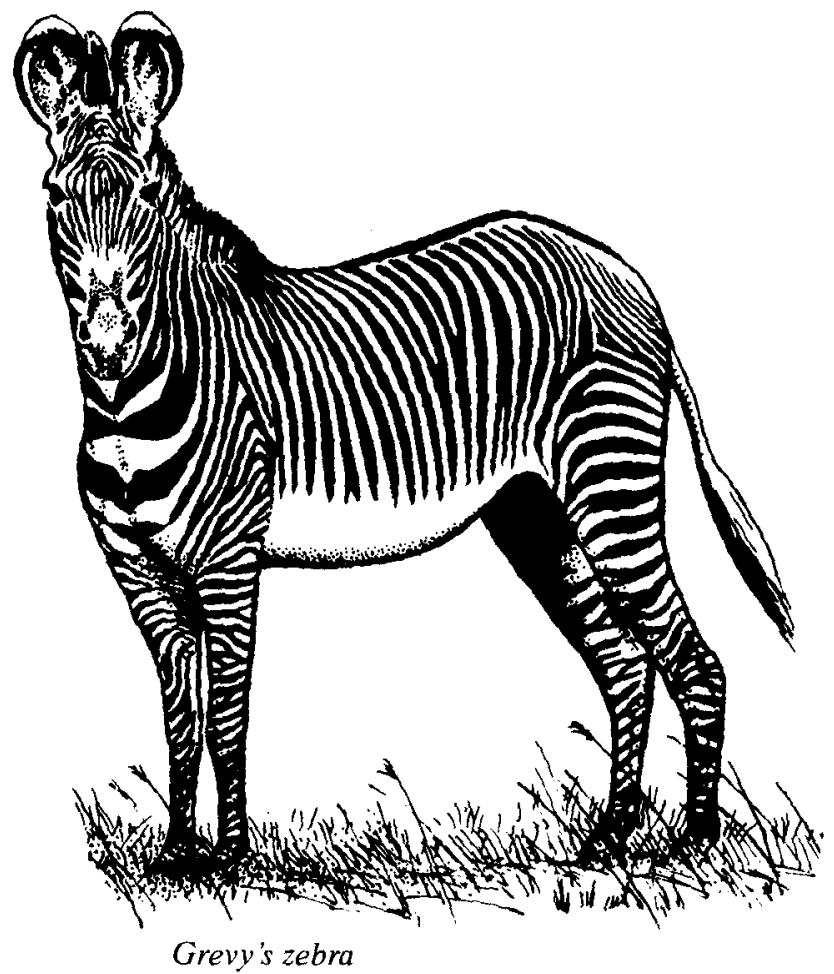

In 1903, when big game hunting was the fashion and few cared about conservation, a group of naturalists, scientists, hunters and game wardens founded the Society for the Preservation of the Wild Fauna of the Empire, now the FPS. It was soon nicknamed the Society for Penitent Butchers.

The Penitent Butchers celebrates the Society's 75 th anniversary. In a lively narrative, Richard Fitter describes the growth of international wildlife conservation and the Society's part in it. Author and artist are giving their royalties to the Oryx 100\% Fund.

Collins, $\mathbf{} \mathbf{2 . 5 0}$

48 pages, hardback

Obtainable from the FPS office for $\$ 2.65$ including $p \& p$. 


\section{ULTRASOUND DETECTORS \\ from \\ QImL Instruments Ltd}

for studies of bats, rodents, insects and dolphins

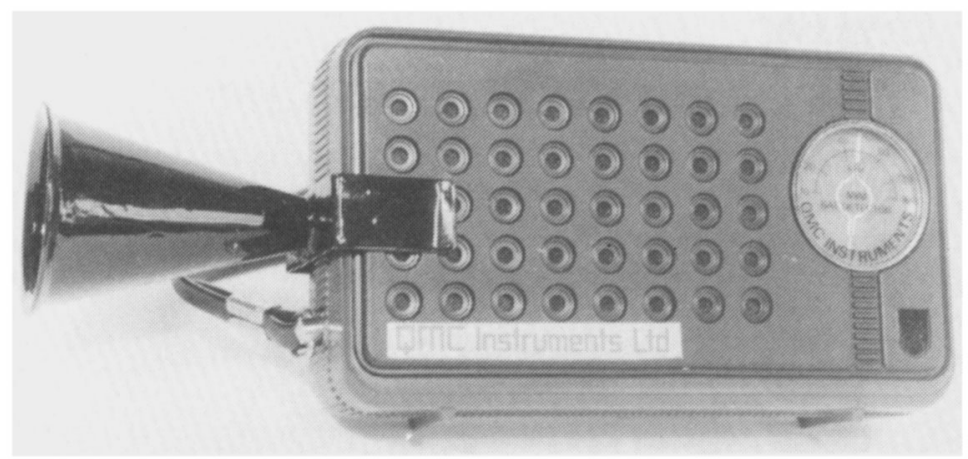

The Mini Bat Detector (pictured above) has been particularly designed for the serious amateur naturalist, and for school or university class work in field or laboratory. It is a pocket-sized, low cost, tuned-only instrument (10 to $160 \mathrm{kHz}$ ), and will operate for weeks on 2 penlite size batteries.

* Sensitivity (at $40 \mathrm{kHz}$ ): $15 \mathrm{~dB}$ S.P.L. with horn

* Output socket for earplug or tape recorder

* Self-illuminated dial pointer

The $\mathbf{S 1 0 0}$ Bat Detector is a high performance superhet instrument with the novel facility of broadband detection and selective frequency analysis (10 to $180 \mathrm{kHz}$ ) in one portable instrument.

* Sensitivity (tuned at $40 \mathrm{kHz}$ ): $11 \mathrm{~dB}$ S.P.L. (broadband, 10 to $180 \mathrm{kHz}$ ): $20 \mathrm{~dB}$ S.P.L.

* Easily replaceable microphone capsules

* Recording sockets for h.f. and a.f. signals

* Weatherproofed, with canvas carrying case

* Microphone can be placed up to 10 m away

* Hydrophone available for underwater studies

Also available: Tunable and Fixed Frequency Ultrasound Generators.

Send for full descriptive literature and price lists.

QMC Instruments Ltd

229 Mile End Road Tel: $01-7900066$ (5 lines) London E1 4AA Telex: 28905 ref.980 


\section{ORNITHOLIDAYS}

1979 MER BRER OF TrE ASSOCATION

HOLIDAYS ORGANISED BY

BIRDWATCHERS FOR BIRDWATCHERS

Ceylon

India

Florida

California

The Seychelles

Kenya

Israel

Morocco

Tunisia

Turkey

Arctic Norway

S. W. Spain
Majorca

Greece

The Camargue

Yugoslavia

Lake Neusiedl

Austrian Alps

Hungary

Romania

Central Wales

Isles of Scilly

Isle of Mull

Isle of Islay

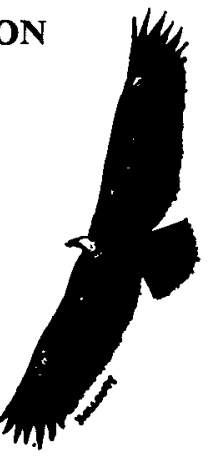

The Solway

The Cairngorms

Hebridean Cruise

Dorset

New Forest

West Sussex

Suffolk

The Farnes \& Bass

\section{LAWRENCE G. HOLLOWAY ORNITHOLIDAYS (Regd.)}

(WESSEX TRAVEL CENTRE)

1/3 VICTORIA DRIVE, BOGNOR REGIS, SUSSEX, ENGLAND PO21 2PW

Telephone 0243321230 


\section{African Journal of Ecology \\ Edited by F.I.B. Kayanja \\ and published quarterly at $£ 27.50$ (U.K.), $£ 30.00$ (overseas), $\$ 70.00$ (U.S.A. and Canada) per annum post free}

This is the new title of the East African Wildlife Journal which was inaugurated to meet the growing need for an authoritative organ for the dissemination of the results of scientific research into East Africa's wildlife. Its scope has now been widened to include original research papers which make a significant contribution to the study of wildlife from any part of Africa, and comprehensive reviews and brief communications are now regular features of the journal.

\section{Australian \\ Journal of Ecology}

Edited by R.L. Kitching

and published quarterly at $€ 24.00$ (U.K.), $£ 27.50$ (overseas), $\$ 90.00$ (U.S.A. and Canada) per annum post free

This newly-established journal, published for the Ecological Society of Australia, is devoted to reports of ecological research and critical reviews of methodology based on work of Australasian origin. Much of the material has a strong theoretical base and will therefore be of relevance to workers in other geographical areas.

Blackwell Scientific Publications Ltd

P.O. Box 88, Oxford, England 


\section{THE FAR EAST}

Specialists for flights to the Far East:

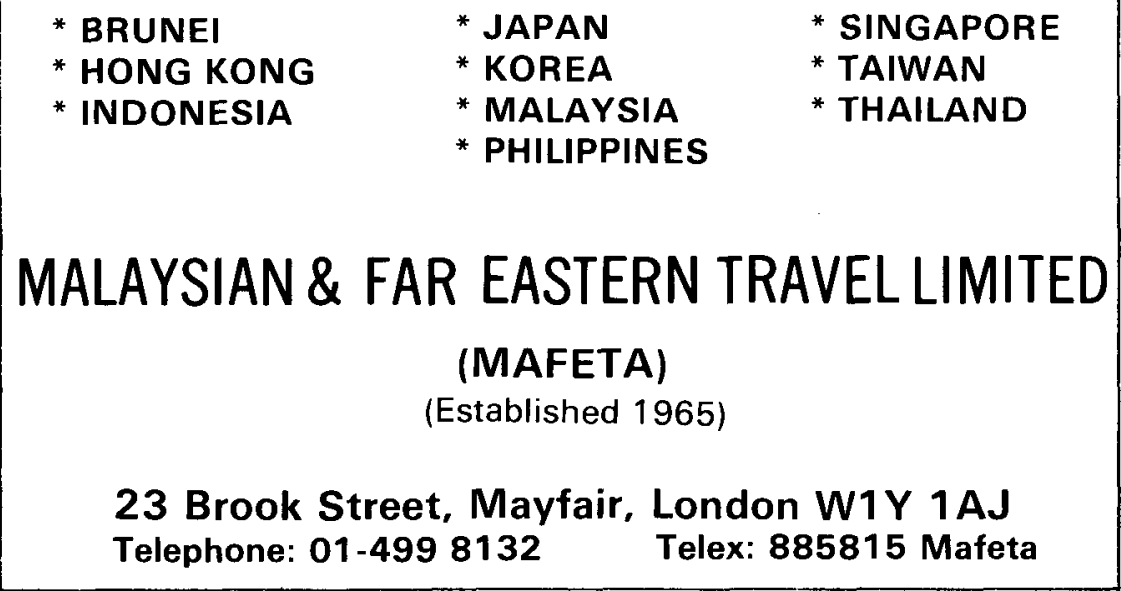

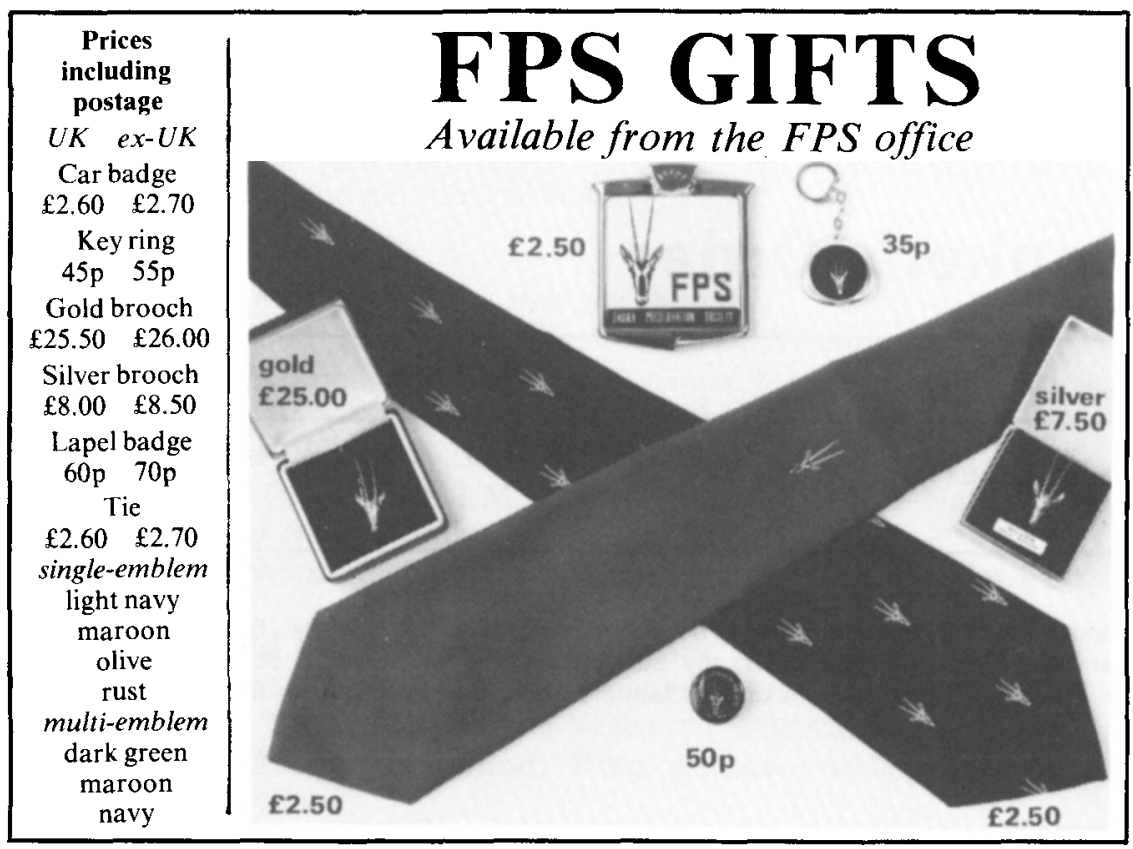




\section{Application for Membership}

The Fauna Preservation Society

c/o The Zoological Society of London, Regent's Park, London NW1 4RY

Please enrol me as a member of the Society

Name (BLOCK LETTERS) Please state $\mathrm{Mr} / \mathrm{Mrs} / \mathrm{Miss}$ or title

Address

I enclose $£ \quad: \quad$ :

being my subscription as a Life/Benefactor/Ordinary Member.

The minimum subscription for Ordinary Members is $£ 5$, US $\$ 12.50$, for Benefactors $£ 10$, US \$25, payable on January 1 st. A Banker's Order saves time, expense and reminders. The value of any subscription is greatly increased if it is paid under a seven-year Deed of Covenant (UK standard-rate income taxpayers only) and this entails no extra cost whatever: write for Covenant forms to the Secretary.

Life membership fees:

Age: Under 41 , £200, US $\$ 485$; age 41-60, £150, US $\$ 385$; age 61 and over, $£ 75$, US $\$ 185$.

\section{Banker's Order}

Bank

Address of Bank

Please pay for the Credit of The Fauna Preservation Society, Barclays Bank Ltd. Camden Town, London NW1, my subscription of $f . . . . . . . . . . .$. due on 1 st January 19 , and a similar amount on 1 st January each year until further notice. 


\section{FPS Wildlife Film Library}

Unless otherwise stated all films are $16 \mathrm{~mm}$ colour with soundtrack. The charges quoted are for one screening only; additional screenings are $£ 2$, or $£ 1$ for older films. All films must be shown by an experienced projectionist. To book a film please write to the Films Officer, FPS, c/o Zoological Society of London, Regent's Park, London NW1 4RY. (Tel: 01-586 0872)

LATEST ADDITION: The Woodmen and the Wild. Management of woodlands and wildlife conservation. Filmed by Lord Dulverton, FPS Council member, on his own estate. 34 mins. f7.50.

At the Crossroads. American wildlife's struggle for survival. Shows endangered species never filmed before. Winner of six awards. 26 mins. $£ 7.50$.

The Last Stronghold. Flying snakes, flying squirrels, and other wildlife in the Malaysian rain forests. Made by WWF Malaysia. 30 mins. $£ 5$.

In Search of the Bowhead Whale. Aerial and underwater photography of bowhead and beluga whales off Alaska. 49 mins. $£ 5$.

Bighorn. Life history of Rocky Mountain bighorn sheep. 26 mins. $£^{5}$.

Ivory Poachers. East African Wildlife Society documentary of the fight against Tsavo elephant poachers. 30 mins. $£ 5$.

On the Third Day. Rare and beautiful plants, insects and vertebrates of the Cape of Good Hope. South African Wildlife Society. 26 mins. $£ 5$.

To Catch a Rhino. Translocation of white rhinos from the Umfolozi Reserve. South African Tourist Corporation, 1962. 20 mins. £3.

Everglades Region. How wildlife adjusts to seasonal fire and floods. 24 mins. f3.

Lake Wilderness. Wildlife of Saint Lucia Lakes. SATOUR. 20 mins. £3. Blesbok. Life history of this South African antelope. 15 mins. $£ 2$.

Whales, Dolphins and Men. Lives, songs and commercial exploitation of cetaceans. BBC Horizon film. 50 mins. $\mathfrak{f}^{5}$.

\section{Older films}

$£ 2$ each or $£ 1$ if hired with a film from the main list.

Peace Game. South Africa's wildlife. SATOUR. 25 mins.

Saiga Saga. Conservation of the saiga antelope. Russian commentary with English subtitles: Soviet Peace Committee. 16 mins.

Koala. Complete life history. H.J. Pollock. 24 mins.

African Lion. Taken by A.I.M. Hepburn in the Kruger National Park. Magnetic sound track. 12 mins.

Mallee Fowl. Nesting habits of a 'mound builder'. CSIRO Film Unit. 11 mins.

Marloo, the Red Kangaroo. By H.J. Pollock. 25 mins.

Le Aye Aye de Madagascar. Black and white. French commentary. By J.-J. Petter and the Service du Film de Recherche Scientifique. 22 mins.

Penguins of Macquarie Island. King, gentoo, rockhopper and royal penguins. 13 mins. 